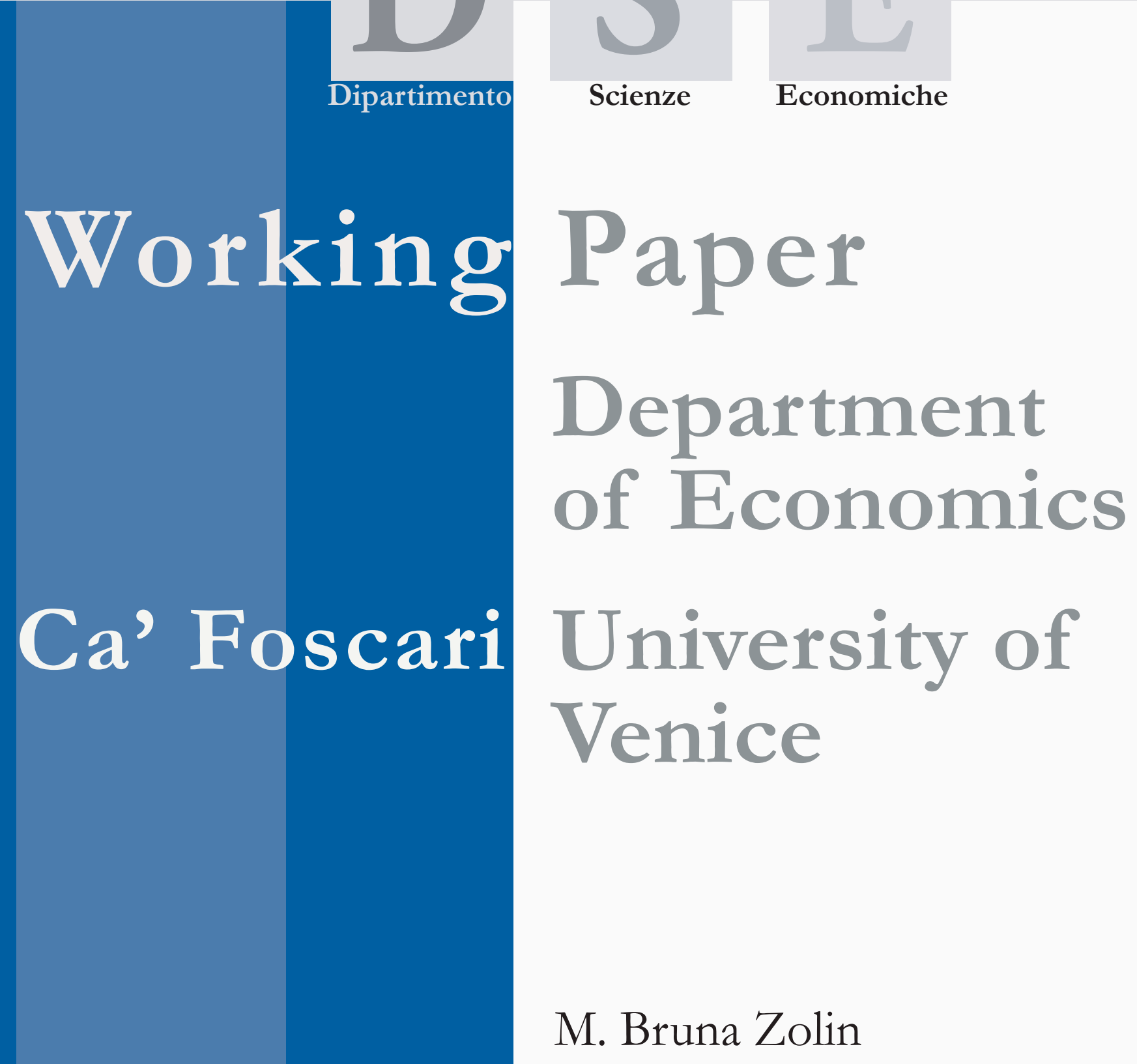

The EU and Asia: World Trade Liberalisation and the Evolution of Agricultural Product Flows 


\title{
The EU and Asia: World Trade Liberalisation and the Evolution of Agricultural Product Flows
}

\author{
M. Bruna Zolin \\ Università Ca’ Foscari di Venezia
}

First Draft: 02.01 .2008

\begin{abstract}
In the trade policy debate, the complete liberalisation of world trade for agricultural products is one of the most relevant issues. European Union is a free trade area where agricultural products are protected and supported from the world market forces, more than any other good or service.

The elimination of trade barriers among the EU member states has achieved European self-sufficiency in food and a strong integration in the European market.

To resolve international disputes, Mc Sharry, Agenda 2000 and Mid Term Reforms of the CAP were introduced in the last decade, having in mind the reduction of domestic support, tariff barriers and export subsides.

In this context, this paper studies the evolution of these trade flows among EU and some selected Asiatic countries. The aim is, on the one hand, to consider the impact of the progressive liberalisation of world agricultural trade in these areas, on the other hand, to measure the integration degree of these groups of countries. In order to be able to study these topics, this paper analyses the evolution of agricultural trade and of the role played by the different product groups.

The paper is divided into three sections, followed by some concluding remarks. The first section studies the main agrarian policies adopted in the EU and some selected Asiatic countries. The second section presents the relationships among them. The third describes the agricultural import and export flows, considering the trade from a general perspective, from the point of view of the political decisions adopted and that of the agreements signed.
\end{abstract}

\section{Keywords}

world trade, agricultural products, Asia and Europe integration.

JEL Codes Q17，Q18，P52

Address for correspondence:

Maria Bruna Zolin

Department of Economics

Ca' Foscari University of Venice Cannaregio 873, Fondamenta S.Giobbe

30121 Venezia - Italy

Phone: (++39) 0412349132

Fax: (++39) 0412349176

e-mail: zolin@unive.it

This Working Paper is published under the auspices of the Department of Economics of the Ca' Foscari University of Venice. Opinions expressed herein are those of the authors and not those of the Department. The Working Paper series is designed to divulge preliminary or incomplete work, circulated to favour discussion and comments. Citation of this paper should consider its provisional character.

Department of Economics

Ca' Foscari University of Venice

Cannaregio 873, Fondamenta San Giobbe

30121 Venice Italy

Fax: ++39 0412349210 


\section{Introduction}

Recently, developed countries have, at least in part, lost their power to decide agricultural policies independently of what is occurring in developing countries. In a context of international negotiation of trade rounds, the domestic programmes of the world's richest countries have been reformed with the intention of eliminating subsidies and allowing developing countries access to large markets ${ }^{1}$. Increasing amounts of primary commodities are being produced, transformed, traded and consumed in a context of difficult conditions. These include: persistent disequilibria between supply and demand, an over-accumulation of stocks and fluctuations in prices. Primary commodity prices are more volatile than manufactured goods. In the trade policy debate, the complete liberalisation of world trade for agricultural products is one of the most important issues. The European Union is a free trade area where agricultural products, more than any other goods or services, are supported and protected from world market forces. To resolve international disputes, a series of reforms of the CAP have been introduced over the last two decades: known as the MacSharry, Agenda 2000 and Mid-Term Reforms. These have had the aim of reducing domestic support, tariff barriers and export subsidies (Daugbjerg, Swinbank, 2007²).

In this context, this paper studies the evolution of trade flows among the EU-25 and selected Asian countries ${ }^{3}$. The aim is, on the one hand, to consider the impact of progressive liberalisation, and, on the other hand, to measure the degree of integration of these groups of countries into world agricultural trade.

The analysed period is 1999-2006. The paper is organised into four sections. The first section describes agricultural sector trends for the world, for selected Asian countries, and for the EU. A second section presents the main agrarian policies adopted by selected Asian countries (namely China, India and Japan), and by the EU. A third section describes agricultural import and export flows between the EU and selected Asian countries. A final section makes some concluding remarks.

\section{The Agricultural Sector}

According to FAO data, the world population rose from 4.4 billion people in 1980 to almost 6.4 billion in 2004, with

\footnotetext{
1 According to the World Bank (2005), over half the gains to developing countries from global agricultural reforms would come from liberalisation by developing countries themselves. The reasons are two-fold: because agricultural tariffs are even higher in developing countries, and because a large minority of developing country trade is now with other developing countries.

2 The authors argue that the actions of the WTO, and the broader international setting, have crucially changed the context for EU CAP reform policy.

${ }^{3}$ Japan, China, India, Hong Kong, Taiwan, Singapore, South Korea, and the ASEAN cluster of countries.
} 
numbers continuing to rise, especially in Asian countries (See Table 1).

Table 1: National Populations (P) and Agricultural Populations (A), 1980-2004: Selected Asian Countries, the EU-25 and the World.

\begin{tabular}{|l|r|r|r|r|r|r|r|r|}
\cline { 2 - 10 } & \multicolumn{4}{c|}{$\begin{array}{c}\text { National Populations } \\
\text { (millions) }\end{array}$} & \multicolumn{3}{c|}{ Agricultural Populations } \\
\cline { 2 - 10 } & $\mathbf{1 9 8 0}$ & $\mathbf{1 9 9 0}$ & $\mathbf{2 0 0 0}$ & $\mathbf{2 0 0 4}$ & $\mathbf{1 9 8 0}$ & $\mathbf{1 9 9 0}$ & $\mathbf{2 0 0 0}$ & $\mathbf{2 0 0 4}$ \\
\hline China & 1.004 & 1.161 & 1.282 & 1.321 & 0.742 & 0.833 & 0.854 & 0.849 \\
\hline Hong Kong & $n \cdot a$. & $n . a$. & $n . a$. & $n . a$. & $n . a$. & $n . a$. & $n . a$. & $n . a$. \\
\hline India & 0.689 & 0.846 & 1.017 & 1.081 & 0.441 & 0.493 & 0.546 & 0.560 \\
\hline Japan & 0.117 & 0.124 & 0.127 & 0.128 & 0.012 & 0.009 & 0.005 & 0.004 \\
\hline South Korea & 0.038 & 0.043 & 0.047 & 0.048 & 0.013 & 0.007 & 0.004 & 0.003 \\
\hline Taiwan & $n \cdot a$. & $n . a$. & $n . a$. & $n . a$. & $n . a$. & $n . a$. & $n . a$. & $n . a$. \\
\hline ASEAN & 0.358 & 0.439 & 0.520 & 0.550 & 0.213 & 0.243 & 0.256 & 0.258 \\
\hline EU-25 & 0.417 & 0.430 & 0.452 & 0.455 & 0.049 & 0.037 & 0.027 & 0.024 \\
\hline Wor1d & 4.435 & 5.263 & 6.070 & 6.378 & 2.220 & 2.442 & 2.573 & 2.600 \\
\hline
\end{tabular}

$\$ 1980,1990$ and 2000 data are average values calculated over the year indicated, the previous year and the following year.

Source: Our elaboration, FAO 2007

For agricultural populations, growth rates have varied: being negative in European nations and in some Asian countries, but positive and growing in China, India and ASEAN $^{4}$ countriesalbeit less than the growth in their national populations (See Table 1).

Table 2: Variations in National (P) and Agricultural (A) Population Growth Rates (1980-2004): Selected Asian Countries, the EU-25 and the World.

\begin{tabular}{|c|c|c|c|c|}
\hline & \multicolumn{2}{|c|}{$\Delta \%$ National Populations $\S$} & \multicolumn{2}{|c|}{$\Delta \%$ Agricultural Populations $₫ \$$} \\
\hline & $1980-2004$ & $2000-2004$ & $1980-2004$ & $2000-2004$ \\
\hline China & 31.54 & 3.01 & 14.42 & -0.49 \\
\hline Hong Kong & n.a. & n.a. & n.a. & n.a. \\
\hline India & 56.93 & 6.33 & 26.83 & 2.58 \\
\hline Japan & 9.42 & 0.61 & -68.72 & -20.91 \\
\hline South Korea & 25.77 & 2.39 & -74.67 & -20.86 \\
\hline Taiwan & n.a. & n.a. & n.a. & n.a. \\
\hline ASEAN & 53.81 & 5.82 & 21.18 & 0.68 \\
\hline$E U-25$ & 9.02 & 0.59 & -51.35 & -13.38 \\
\hline World & 43.80 & 5.06 & 17.15 & 1.06 \\
\hline
\end{tabular}

Source: Our elaboration, FAO 2007

\footnotetext{
${ }^{4}$ Association of South-East Asian Nations. The Member countries are: Brunei Darussalam, Cambodia, Indonesia, Laos, Malaysia, Myanmar, the Philippines, Singapore, Thailand, and Vietnam.
} 
Over the period 1980 to 2004, the worldwide production of cereals increased from almost 1.6 to 2.3 million tons, a rise of 44 per cent; and the production of meat increased from 136 to 260 million tons, a rise of 90 per cent. Cereal growth rates were not much higher than global population growth rates (i.e. global population growth: +43.8 per cent, cereal growth: +44.3 per cent); but meat production increases were significantly higher (+90.9 per cent). Cereal growth rates were very high in ASEAN countries ( +97.9 per cent for cereals, compared with +53.8 per cent for total population), India ( +68 per cent for cereals, and +57 per cent for national population), China (+ 44 per cent for cereals, and +31 per cent for national population), and in the EU-25 (+46 per cent for cereals, and +9 per cent for total population). The production of meat strongly increased in China, South Korea, and ASEAN countries (See Tables 2, 3 and 4).

Table 3: Territorial Areas and Arable Land Areas (1980-2000): Selected Asian Countries, the EU-25 and the World.

\begin{tabular}{|c|c|c|c|c|c|c|c|c|}
\hline & \multirow[t]{2}{*}{\begin{tabular}{|c}
$\begin{array}{c}\text { Territorial } \\
\text { areas } \\
\text { (thousand } \\
\text { ha) }\end{array}$ \\
2000
\end{tabular}} & \multicolumn{3}{|c|}{$\begin{array}{c}\text { Arable Land Areas } \\
\text { (thousand ha) }\end{array}$} & \multirow[t]{2}{*}{$\begin{array}{c}\text { Arable } \\
\text { Land / } \\
\text { Territorial } \\
\text { Area (\%) } \\
2000\end{array}$} & \multicolumn{3}{|c|}{$\begin{array}{l}\text { Arable Land } \\
\text { Per Cap. } \\
\text { Agricultural } \\
\text { Population } \\
\text { ha }\end{array}$} \\
\hline & & 1980 & 1990 & 2000 & & 1980 & 1990 & 2000 \\
\hline China & 932,742 & 96,924 & 123,678 & 137,124 & 14.7 & 0.13 & 0.15 & 0.16 \\
\hline $\begin{array}{l}\text { Hong } \\
\text { Kong }\end{array}$ & $n . a$. & $n \cdot a$. & $n . a$. & n.a. & n.a. & n. $a$. & n.a. & n.a. \\
\hline India & 297,319 & 162,955 & 162,788 & 160,555 & 54.0 & 0.37 & 0.33 & 0.29 \\
\hline Japan & 36,450 & 4,874 & 4,768 & 4,474 & 12.3 & 0.39 & 0.55 & 0.91 \\
\hline $\begin{array}{l}\text { South } \\
\text { Korea }\end{array}$ & 9,873 & 2,060 & 1,953 & 1,718 & 17.4 & 0.16 & 0.28 & 0.42 \\
\hline Taiwan & $n . a$. & n.a. & $n \cdot a$. & n.a. & $n \cdot a$. & n.a. & n.a. & n.a. \\
\hline ASEAN & 434,548 & 59,041 & 64,331 & 64,531 & 14.9 & 0.28 & 0.26 & 0.25 \\
\hline$E U-25$ & 384,862 & 97,971 & 96,761 & 103,047 & 26.8 & 2.01 & 2.61 & 3.77 \\
\hline World & $13,004,202$ & $1,345,989$ & $1,395,973$ & $1,397,656$ & 10.7 & 0.61 & 0.57 & 0.54 \\
\hline
\end{tabular}


Table 4: Production of Cereals (C) and Variation in Growth (1980-2004): Selected Asian Countries, the EU-25 and the World.

\begin{tabular}{|c|c|c|c|c|c|c|}
\hline & \multicolumn{4}{|c|}{$\begin{array}{l}\text { Production of Cereals } \\
\text { (thousand tonnes) }\end{array}$} & \multicolumn{2}{|c|}{\begin{tabular}{|c|}
$\Delta \%$ \\
Production \\
of Cereals
\end{tabular}} \\
\hline & 1980 & 1990 & 2000 & 2004 & \begin{tabular}{|c|}
$1980-$ \\
2004
\end{tabular} & $\begin{array}{c}2000- \\
2004\end{array}$ \\
\hline China & 286,488 & 390,171 & 420,308 & 413,166 & 44.22 & -1.70 \\
\hline Hong Kong & $n . a$. & n.a. & n.a. & n.a. & n.a. & n.a. \\
\hline India & 138,182 & 195,478 & 238,012 & 232,360 & 68.16 & -2.37 \\
\hline Japan & 14,318 & 13,946 & 12,444 & 11,990 & $16.26^{-}$ & -3.65 \\
\hline South Korea & 8,452 & 8,412 & 7,606 & 7,325 & \begin{tabular}{r|}
- \\
13.33 \\
\end{tabular} & -3.69 \\
\hline Taiwan & n.a. & n.a. & n.a. & n.a. & n.a. & n.a. \\
\hline ASEAN & 94,521 & 129,273 & 172,013 & 187,092 & 97.94 & 8.77 \\
\hline$E U-25$ & 200,602 & 244,302 & 259,083 & 292,718 & 45.92 & 12.98 \\
\hline World & $1,573,227$ & $1,903,961$ & $2,084,615$ & $2,270,360$ & 44.31 & 8.91 \\
\hline
\end{tabular}

Arable land accounts for nearly 10 per cent of the total territorial area in the countries analysed, of which India has the greatest arable surface, followed by China and the EU-25. An analysis of how much arable land there is per head of agricultural population in the countries studied shows that the best situation is held by the EU-25 with a surface area per capita equal to 3.8 hectares, in 2000 (See Table 5). In contrast, in Asian countries arable land per head of agricultural population is very small, with China, for example, only having an average of 0.16 hectares per person (See Table 5). 
Table 5: Territorial Areas and Arable Land Areas (1980-2000): Selected Asian Countries, the EU-25 and the World.

\begin{tabular}{|c|c|c|c|c|c|c|c|c|}
\hline & \multirow[t]{2}{*}{\begin{tabular}{|c|}
$\begin{array}{c}\text { Territorial } \\
\text { areas } \\
\text { (thousand } \\
\text { ha) }\end{array}$ \\
2000 \\
\end{tabular}} & \multicolumn{3}{|c|}{$\begin{array}{c}\text { Arable Land Areas } \\
\text { (thousand ha) }\end{array}$} & \multirow[t]{2}{*}{\begin{tabular}{|c|} 
Arable \\
Land / \\
Territorial \\
Area (\%) \\
2000 \\
\end{tabular}} & \multicolumn{3}{|c|}{$\begin{array}{c}\text { Arable Land } \\
\text { Per Cap. } \\
\text { Agricultural } \\
\text { Population } \\
\text { ha }\end{array}$} \\
\hline & & 1980 & 1990 & 2000 & & 1980 & 1990 & 2000 \\
\hline China & 932,742 & 96,924 & 123,678 & 137,124 & 14.7 & 0.13 & 0.15 & 0.16 \\
\hline $\begin{array}{l}\text { Hong } \\
\text { Kong }\end{array}$ & $n . a$. & n. $a$. & $n . a$. & n. $a$. & $n . a$. & n. $a$. & n. $a$. & n.a. \\
\hline India & 297,319 & 162,955 & 162,788 & 160,555 & 54.0 & 0.37 & 0.33 & 0.29 \\
\hline Japan & 36,450 & 4,874 & 4,768 & 4,474 & 12.3 & 0.39 & 0.55 & 0.91 \\
\hline $\begin{array}{l}\text { South } \\
\text { Korea }\end{array}$ & 9,873 & 2,060 & 1,953 & 1,718 & 17.4 & 0.16 & 0.28 & 0.42 \\
\hline Taiwan & n.a. & n.a. & n.a. & n.a. & n.a. & n.a. & n.a. & n.a. \\
\hline ASEAN & 434,548 & 59,041 & 64,331 & 64,531 & 14.9 & 0.28 & 0.26 & 0.25 \\
\hline$E U-25$ & 384,862 & 97,971 & 96,761 & 103,047 & 26.8 & 2.01 & \begin{tabular}{|l|}
2.61 \\
\end{tabular} & 3.77 \\
\hline World & $13,004,202$ & $1,345,989$ & $1,395,973$ & $1,397,656$ & 10.7 & 0.61 & 0.57 & 0.54 \\
\hline
\end{tabular}

In order to highlight different degrees of productivity of land and labour, we have calculated some indices that measure the production of cereals and meat in relation to i.) the availability of arable land, and ii.) the size of agricultural populations (See Tables 6, 7,8 and 9).

The indicator for the production of cereals relative to agricultural population shows a very low worldwide increase (rising from 0.7 in 1980 to 0.9 in 2004) (See Table 6). In EU countries, however, the period between 1980 and 2000 experienced a doubling of average productivity (from 4.1 to 9.5), while increases in the other countries were quite low.

We have also calculated productivity increases using the indicator "Relative Increase of Labour Factor" ( $\Delta$ Production of cereals / $\Delta$ Agricultural population) which measures increases in production relative to increases in labour. For cereals, this indicator is generally increasing in Asian countries (in particular in ASEAN countries) (See Table 6). In India, however, the indicator is decreasing, while average productivity is increasing. 
Table 6: Production of Cereals (C) / Agricultural Population (A), and Relative Increase of Labour Factor (1980-2004): Selected Asian Countries, the EU-25 and the World.

\begin{tabular}{|c|c|c|c|c|c|c|c|}
\hline & \multicolumn{4}{|c|}{$\begin{array}{l}\text { Production of Cereals / } \\
\text { Agricultural Population }\end{array}$} & \multicolumn{3}{|c|}{$\begin{array}{l}\text { Relative Increase of } \\
\text { Labour Factor } \mathbb{}\end{array}$} \\
\hline & 1980 & 1990 & 2000 & 2004 & 1980-1990 & $1990-2000$ & 2000-2004 \\
\hline China & 0.39 & 0.47 & 0.49 & 0.49 & 1.14 & 1.47 & 1.71 \\
\hline Hong Kong & n.a. & n.a. & n.a. & n.a. & n.a. & n.a. & n.a. \\
\hline India & 0.31 & 0.40 & 0.44 & 0.42 & 1.10 & 0.81 & 0.40 \\
\hline Japan & 1.15 & 1.62 & 2.53 & 3.08 & 0.10 & 0.41 & 0.44 \\
\hline South Korea & 0.66 & 1.20 & 1.85 & 2.25 & 0.01 & 0.28 & 0.33 \\
\hline Taiwan & n.a. & n.a. & n.a. & n.a. & n.a. & n.a. & n.a. \\
\hline ASEAN & 0.44 & 0.53 & 0.67 & 0.72 & 1.16 & 3.18 & 8.64 \\
\hline$E U-25$ & 4.12 & 6.60 & 9.48 & 12.36 & 3.75 & 1.53 & 9.19 \\
\hline World & 0.71 & 0.78 & 0.81 & 0.87 & 1.48 & 1.38 & 6.84 \\
\hline
\end{tabular}

$\S \Delta$ Production of cereals / $\Delta$ Agricultural population: $\left(\mathrm{C}_{\mathrm{t}}-\mathrm{C}_{\mathrm{t}-\mathrm{n}}\right) /\left(\mathrm{A}_{\mathrm{t}}-\right.$

$$
\left.A_{t-n}\right)
$$

Source: Our elaboration, FAO 2007

In respect of meat, the indicator "production of meat/agricultural population" increased globally from 0.06 to 0.10. As for cereals, in respect of meat production European productivity rates are the highest (See Table 7). In respect of the relative increase of labour factor indicator for meat production, less pronounced variations than for cereals can be observed (See Table 7).

Between 1980 and 2000, land productivity increased more gradually than for labour, while the indicator "relative increase of arable land factor " highlights a very high variability, in particular with reference to cereals production (See Tables 8 and 9). 
Table 7: Production of Meat (M)/ Agricultural Population

(A) and Relative Increase of Labour Factor (1980-2004): Selected Asian Countries, the EU-25 and the World.

\begin{tabular}{|c|c|c|c|c|c|c|c|}
\hline & \multicolumn{4}{|c|}{$\begin{array}{c}\text { Production of Meat / } \\
\text { Agricultural } \\
\text { Population }\end{array}$} & \multicolumn{3}{|c|}{$\begin{array}{c}\text { Relative Increase of } \\
\text { Labour Factor } \mathbb{}\end{array}$} \\
\hline & 1980 & 1990 & 2000 & 2004 & $\begin{array}{c}1980- \\
1990\end{array}$ & $\begin{array}{c}1990- \\
2000\end{array}$ & $\begin{array}{c}2000- \\
2004\end{array}$ \\
\hline China & 0.02 & 0.04 & 0.07 & 0.09 & 0.18 & 1.57 & 2.74 \\
\hline Hong Kong & $n . a$. & n.a. & n.a. & $n \cdot a$. & n.a. & n.a. & n.a. \\
\hline India & 0.01 & 0.01 & 0.01 & 0.01 & 0.02 & 0.03 & 0.05 \\
\hline Japan & 0.24 & 0.41 & 0.61 & 0.78 & 0.13 & 0.14 & 0.04 \\
\hline South Korea & 0.04 & 0.13 & 0.41 & 0.54 & 0.08 & 0.25 & 0.09 \\
\hline Taiwan & n.a. & n.a. & n.a. & n.a. & n.a. & $n . a$. & n.a. \\
\hline ASEAN & 0.02 & 0.03 & 0.04 & 0.04 & 0.09 & 0.23 & 1.20 \\
\hline$E U-25$ & 0.69 & 1.01 & 1.54 & 1.79 & 0.34 & 0.48 & 0.10 \\
\hline World & 0.06 & 0.07 & 0.09 & 0.10 & 0.19 & 0.42 & 0.94 \\
\hline
\end{tabular}

${ }^{s} \Delta$ Production of meat / $\Delta$ Agricultural population: $\left(\mathrm{M}_{\mathrm{t}}-\mathrm{M}_{\mathrm{t}}\right.$ n) / $\left(A_{t}-A_{t-n}\right)$

Source: Our elaboration, FAO 2007

Table 8: Production of Cereals (C) / Territorial Area;

Production of Cereals / Arable Land (L); and Relative Increase of Arable Land Factor (1980-2000): Selected Asian Countries, the EU-25 and the World.

\begin{tabular}{|l|r|r|r|r|r|r|}
\cline { 2 - 8 } & $\begin{array}{c}\text { Production of } \\
\text { Cereals / } \\
\text { Territorial } \\
\text { Area }\end{array}$ & \multicolumn{2}{c|}{$\begin{array}{c}\text { Production of } \\
\text { Cereals / Arable } \\
\text { Land }\end{array}$} & \multicolumn{2}{c|}{$\begin{array}{c}\text { Relative } \\
\text { Increase of } \\
\text { Arable Land } \\
\text { Factor }\end{array}$} \\
\cline { 2 - 9 } & $\mathbf{2 0 0 0}$ & $\mathbf{1 9 8 0}$ & $\mathbf{1 9 9 0}$ & $\mathbf{2 0 0 0}$ & $\begin{array}{c}\mathbf{1 9 8 0 -} \\
\mathbf{1 9 9 0}\end{array}$ & $\begin{array}{c}\mathbf{1 9 9 0 -} \\
\mathbf{2 0 0 0}\end{array}$ \\
\hline China & 0.451 & 2.96 & 3.15 & 3.07 & 3.88 & 2.24 \\
\hline Hong Kong & $n . a$. & $n . a$. & $n . a$. & $n . a$. & $n . a$. & $n . a$. \\
\hline India & 0.255 & 0.85 & 1.20 & 1.48 & 343.09 & 19.05 \\
\hline Japan & 0.013 & 2.94 & 2.92 & 2.78 & 3.52 & 5.11 \\
\hline South Korea & 0.008 & 4.10 & 4.31 & 4.43 & 0.37 & 3.43 \\
\hline Taiwan & $n . a$. & $n . a$. & $n . a$. & $n . a$. & $n . a$. & $n . a$. \\
\hline ASEAN & 0.184 & 1.60 & 2.01 & 2.67 & 6.57 & 213.70 \\
\hline EU-25 & 0.278 & 2.05 & 2.52 & 2.51 & 36.12 & 2.35 \\
\hline World & 2.235 & 1.17 & 1.36 & 1.49 & 6.62 & 107.34 \\
\hline
\end{tabular}

$\checkmark \Delta$ Production of cereals / $\Delta$ Arable land: $(\mathrm{Ct}-\mathrm{Ct}-\mathrm{n}) /(\mathrm{Lt}-\mathrm{Lt}-\mathrm{n})$ Source: Our elaboration, FAO 2007 
Table 9: Production of Meat (M) / Arable Land (L) and Arable Land Factor Relative Increase (1980-2000).

\begin{tabular}{|c|c|c|c|c|c|}
\hline & \multicolumn{5}{|c|}{ Factor Relative Increase (1980-2000). } \\
\hline & \multicolumn{3}{|c|}{$\begin{array}{c}\text { Production of meat / } \\
\text { Arable land }\end{array}$} & \multicolumn{2}{|c|}{$\begin{array}{l}\text { Relative Increase of } \\
\text { Arable Land Factor }\end{array}$} \\
\hline & 1980 & 1990 & 2000 & $1980-1990$ & $1990-2000$ \\
\hline China & 0.15 & 0.25 & 0.46 & 0.60 & 2.39 \\
\hline Hong Kong & n.a. & n.a. & n.a. & n.a. & n.a. \\
\hline India & 0.02 & 0.02 & 0.03 & 7.55 & 0.62 \\
\hline Japan & 0.62 & 0.73 & 0.67 & 4.68 & 1.76 \\
\hline South Korea & 0.23 & 0.48 & 0.97 & 4.29 & 3.16 \\
\hline Taiwan & n.a. & n.a. & n.a. & n.a. & n.a. \\
\hline ASEAN & 0.06 & 0.10 & 0.14 & 0.48 & 15.57 \\
\hline$E U-25$ & 0.34 & 0.39 & 0.41 & 3.30 & 0.73 \\
\hline World & 0.10 & 0.13 & 0.17 & 0.87 & 32.69 \\
\hline
\end{tabular}

\section{The Main Agrarian Policies in Selected Countries}

\subsection{Asian Countries}

In order to analyse the effects of policies on free trade we selected a cluster of Asian countries composed of China, India and Japan. The first two are strong performers according to recent trade trends. The third, Japan, has a low production of agricultural products and consequently has an important influence on trade. In fact, according to the International Monetary Fund (April 2007), in terms of GDP (Gross Domestic Product) by purchasing power parity China has the largest economy in Asia, followed by Japan and India. Generally, Asia has a well-established tradition in agriculture.

\section{China}

In China, the agricultural sector is affected by a mountainous terrain and climate which make a significant portion of the Chinese territory unsuitable for cultivation. In fact, the area under cultivation amounts to about 13-15 per cent of the total territory, of which a very small percentage (4 per cent) is occupied by permanent crops. About 75 per cent of China's cultivated land area is used for food crops (of which the main cereal products are rice, wheat, maize and soy, while the chief industrial crops are cotton, peanuts, rape, sugar cane and sugar beet). Arable land averages at less than 1 hectare per household. The small extent of available agricultural land is counterweighted by the development of multiple harvests (two or three times a year). As the agricultural sector absorbs the greatest part of the national population, agriculture is mainly carried out using extensive practices. Chinese policies have often changed direction. The Maoist revolution in 1949 forced collectivisation 
and the abolition of private property. Expropriated fields were allocated to households, commensurate with the number of their members, and production (with minimum quantitative limits) was allocated to the Commune which would distribute it according to different needs. In 1978 the re-introduction of the family farm launched de-collectivization. Deng Xiaoping's reforms activated economic development which made China one of the greatest economic world powers. An explosion of agricultural production began in 1978 when the rate of growth was double that of the previous twenty years. The production of cereals (maize, wheat, and rice), tuberous plants and soya bean increased, and the growth of cotton, oil products and animal breeding was even faster. Government incentives were introduced in order to constrain a rapid excess of urbanisation and also to facilitate the introduction of new technologies. Despite the fact that China is able to produce most types of food, and it possesses a comparative advantage in labour intensive products, the limited availability of other factors of production (mainly water resources) constrains the agricultural sector's productive capacity. In the last five years, export volumes of all products from Europe to China have grown considerably ${ }^{5}$,. China's admission to the WTO and its effects on the country's agriculture were a matter of concern because, despite fast industrialisation, agriculture is still an important part of GDP and it provides half of total Chinese employment. Today, there are about 240 million agricultural households in China, most of them cultivating small plots of land. However, a great part of them, above all the ones producing products like wheat, maize, sugar and soya bean, could suffer a revenue reduction when lower priced imported products arrive on local markets.

Competitive pressures imposed by global markets not only have negative effects. They have also induced a deep reorganisation of the entire agricultural sector, including production methods, technologies and distribution systems. Moreover, in order to promote the vitality of the primary sector, the Beijing authorities have launched tax reduction policies in order to accelerate rural modernisation and balance urban and rural development.

India

Agriculture is one of the most important sectors of the Indian economy. Agriculture and its by-products contribute nearly 22 per cent of GDP, while about 65-70 per cent of the population is dependent on agriculture for their livelihoods. However, agricultural output is heavily dependent on the monsoon (Government of India, 2008). According to FAO, the total cultivated area in India is estimated to cover about 54 per cent

\footnotetext{
${ }^{5}$ Increasing from 110 million Euros in 2001 to 206 million Euros by 2005. In 2006, EU imports of agricultural products from China had a value of 3.8 million Euros while the export value was 1.4 million Euros
} 
of the total national territory. The extent of the area under cultivation increased from 1950 to 1970 by 18 per cent per year, but from 1980 it decreased (from 163 million hectares in 1980 to 160 million in 2000). The average farm size is very small, estimated at 1.57 hectares. A varied climate makes possible the production of a large range of products. India is the biggest producer in the world of dairy products, the leading producer of tea and spices, the second biggest producer of fruits and sugar cane and the third biggest producer of cereals, after China and the USA. It is also the country with the highest number of cattle. Nevertheless, there are still some problems to be resolved if the agricultural sector is to be further developed. Experts in fact think that there are serious irrigation problems and they assess that only 33 per cent of soils can make use of the existing irrigation network. Moreover, many irrigation improvement projects, planned in 1997, have not yet been completed.

The Indian Government has announced its objectives: to double the rate of growth of irrigated areas; to reclaim degraded land and improve soil quality; to improve water management, rain water harvesting and watershed development; to bridge the knowledge gap through effective extension services; to diversify into high value products, including in respect of fruit, vegetables, flowers, herbs and spices, medicinal plants, bamboo, and bio-diesel, but with adequate measures to ensure security of national food supply; and to provide easy access to credit at affordable rates.

In respect of the trade in agricultural products between the EU and India, for a long time there have been complaints from India about the existence of subsidies in the European agricultural system.

Japan

Agriculture in Japan has a very low weight in GNP. Only 12 per cent of Japan's territory is suitable for cultivation and the land is intensively cultivated. The agricultural sector employs a relatively large proportion of the working population in comparison to its contribution to national income, but the percentage of the workforce in agriculture is decreasing. Many farmers have left, and are leaving, agriculture for manufacturing and service sector employment, and most others have to rely on non-farm sectors for a significant part of their income. Japanese agriculture is characterised by a large number of small farms. The agricultural sector is subsidised and protected. The country's principal crop is rice. Other important farm products include wheat, barley, potatoes, fruit, vegetables, and tea. With per unit area crop yields among the highest in the world, and an agricultural selfsufficiency rate of about 50 per cent, Japan produces a small surplus of rice, but imports large quantities of wheat, sorghum and soya bean. 
The government's agricultural policy has encouraged selfsufficiency in the more important commodities (although it has in fact been achieved only for rice), sought to enlarge the size of the average holding, and to close the gap between rural and urban incomes. The central feature of the policy has been an artificially high producer price for rice. This has succeeded in raising farm incomes and has led to increases in rice production. Although a limited liberalisation of agricultural products has been started, strong protective barriers curb the import of rice and other products. For a long time, in fact, Japanese commercial policy has utilised quantitative controls on imports as a tool for protecting its own market.

The main destinations of Japanese agricultural exports are the USA and Asian countries.

\subsection{The European Union}

If in developed countries (among them the EU) agricultural protection is designed to achieve a range of general objectives (such as environmental safeguards, food quality and safety, animal welfare, workplace safety, and others), in many other countries (including some Asian countries) it is mainly aimed at achieving food self-sufficiency.

Some primary commodities are affected by special difficulties that necessitate special treatment such as inter-governmental agreements. According to Article 37 of the Treaty, the Council of the European Union, acting on proposals from the European Commission and in consultation with the European Parliament, is required to establish market organisations which are then run by the Commission. These market organisations exist for most agricultural products produced within the EU. Their primary functions are to set common prices, grant aid to producers, control production and regulate trade. The market agencies may require importers to obtain import licenses or pay import levies and may take measures to safeguard the community market. The agencies also pay subsidies to EU exporters to bring their prices in line with world markets. The CAP has evolved since its introduction. The early policy of community preference, adopted by the European Council in 1962, gave preferences and price advantages to EU agricultural products over imported goods and protected the internal market from price fluctuations and cheap imported products. Over time, the European Union's Common Agriculture Policy has undergone a number of incremental changes aimed at addressing the imbalance between supply and demand $^{6}$. In 1992, as a consequence of pressures on the CAP arising from international trade negotiations, and also serious budgetary concerns, prices were reduced in an effort to become

${ }^{6}$ For example fixed quotas on milk production, and voluntary set-aside. 
more competitive in the international market. The MacSharry reform modified the price support system. There was a shift from a dependence on product price support to direct payments to farmers ${ }^{7}$. In the cereals sector where the product price was reduced by a third, the farmers were compensated for revenue loss with a subsidy paid on land on which an eligible arable crop was grown (known as the Arable Area Payment Scheme). Also, beef support prices were reduced and in compensation cattle headage payments were established. A new series of reforms of the CAP began in 1997 (known as Agenda 2000) in preparation for the enlargement of the EU and the implementation of the Uruguay Round agreements of the WTO (European Commission 1999 and 2000). The reforms, known as a deepening of the MacSharry reform, contained measures aimed at making the EU more competitive in the global agricultural market, doing away with trade distorting practices, and allowing farmers to produce what the world market demands. Further future cuts in intervention prices with partial compensation through an increase in direct payments were anticipated ${ }^{8}$. The budget was fixed for the period 2000-2006 to help farmers plan for the medium term and to reassure taxpayers that projected CAP costs would not be exceeded. The core of the Fischler reform in $2003^{9}$ (European Commission, 2002) involved a change of policy instruments. Direct aid payments were transformed into a new single payment scheme which was made conditional on the individual farmer's compliance with a number of environmental, animal health and welfare and food safety regulations. The result of these changes was a remarkable decoupling of payments from production, albeit there remained a significant link with farming due to the restrictions that accompanied the payments.

At European level, agriculture and forests, as main users of land, occupy the large majority of the territory and play a significant role in determining the health of rural economies as well as the rural landscape. In fact, the EU could be classified as predominantly rural, according to OECD (Organisation for Economic Co-operation and Development) classification. Most farms are small to medium-sized, and are often family run. Agricultural activities perform many different functions (including nature conservation, tourism, and the production of non- food agricultural products), but their primary role is the production of food. CAP subsidies and improvements in farm efficiency have encouraged a strong increase in food production leading ultimately to surpluses of many farm goods. Europe can produce a wide range of agricultural products, and for many

\footnotetext{
${ }^{7}$ Partially shifting the cost from consumers to taxpayers.

8 Another intention was to re-organise structural policy and place more emphasis on rural development and the environment.

${ }^{9}$ This entered into force in 2004-2005.
} 
products it is considered the world leader, but for others it is the largest importer.

\section{Imports and Exports of Agricultural Products}

Recently, new driving forces have altered the pattern of global production and trade. These forces include: income growth (mainly in developing Asian countries, such as India and China) which has resulted in increased consumption of food ${ }^{10}$; climate change; high energy prices ${ }^{11}$; globalisation; ${ }^{12}$ and increasing urbanisation. ${ }^{13}$

At the world level, agricultural production has grown where population has also grown. According to FAO statistics, in the developing world production and consumption have been growing at a higher rate than in either the developed countries or the economies in transition. A stable growth of total world production is in contrast to a European constant output which is constrained by the setting of pre-determined quantities.

Table 10: European Agricultural Exports to Selected Asian Countries (€Millions, 1999-2006).

\begin{tabular}{|c|c|c|c|c|c|c|c|c|}
\hline & 1999 & 2000 & 2001 & 2002 & 2003 & 2004 & 2005 & 2006 \\
\hline Japan & 3,742 & 4,300 & 4,435 & 4,196 & 3,971 & 4,110 & 4,014 & 4,087 \\
\hline China & 797 & 745 & 645 & 683 & 820 & 1,012 & 1,230 & 1,371 \\
\hline India & 276 & 154 & 182 & 209 & 199 & 184 & 197 & 347 \\
\hline $\begin{array}{l}\text { Hong } \\
\text { Kong }\end{array}$ & 1,072 & 1,360 & 1,415 & 1,222 & 1,088 & 1,216 & 1,232 & 1,546 \\
\hline Taiwan & 659 & 777 & 761 & 751 & 686 & 709 & 738 & 755 \\
\hline $\begin{array}{l}\text { South } \\
\text { Korea }\end{array}$ & 811 & 976 & 970 & 1,146 & 877 & 973 & 1,081 & 1,193 \\
\hline ASEAN & 1,801 & 2,378 & 2,243 & 2,111 & 2,019 & 2,229 & 2,378 & 2,524 \\
\hline $\begin{array}{l}\text { Total exports } \\
\text { (agricultural } \\
\text { products) }\end{array}$ & 9,158 & 10,690 & 10,651 & 10,318 & 9,660 & 10,433 & 10,870 & 11,823 \\
\hline $\begin{array}{l}\text { Total exports } \\
\text { (all } \\
\text { products) }\end{array}$ & 137,349 & 179,194 & 183,793 & 182,805 & 181,531 & 201,300 & 214,987 & 238,333 \\
\hline
\end{tabular}

Source: Our elaboration, EUROSTAT 2006.

European exports of agricultural products to the selected Asian countries increased from 9 million euros in 1999 to 11 million in 2006, an increase of 31 per cent (See Table 10). Japan is the leading importer from Europe (taking 34.6 per cent of European agricultural exports to the selected Asian countries), followed by ASEAN countries (21 per cent). India has the lowest share ( 3 per cent).

10 The composition of food budgets is shifting from the consumption of low-value to high-value products..

11 Rising energy costs are increasingly being translated into higher food prices.

12 Globalisation is affecting consumption patterns, especially in Asia and urban areas.

${ }^{13}$ Urban populations are more exposed to non- traditional foods. 
By comparing two different periods (before and after the CAP reforms Agenda 2000 and Fischler) we can see that over the last years (2003-2006) EU exports of agricultural products increased by 25 per cent, in comparison with 12.1 per cent in the first period. If we consider exports of all products there was an increase between 1999 and 2006 of 72 per cent, but in this case it was fairly shared between the two periods.

Figure 1: Agriculture Products: EU Exports to Selected Asian Countries: per cent Rate of Variation: 1999-2006, 1999-2002, 2003-2006.

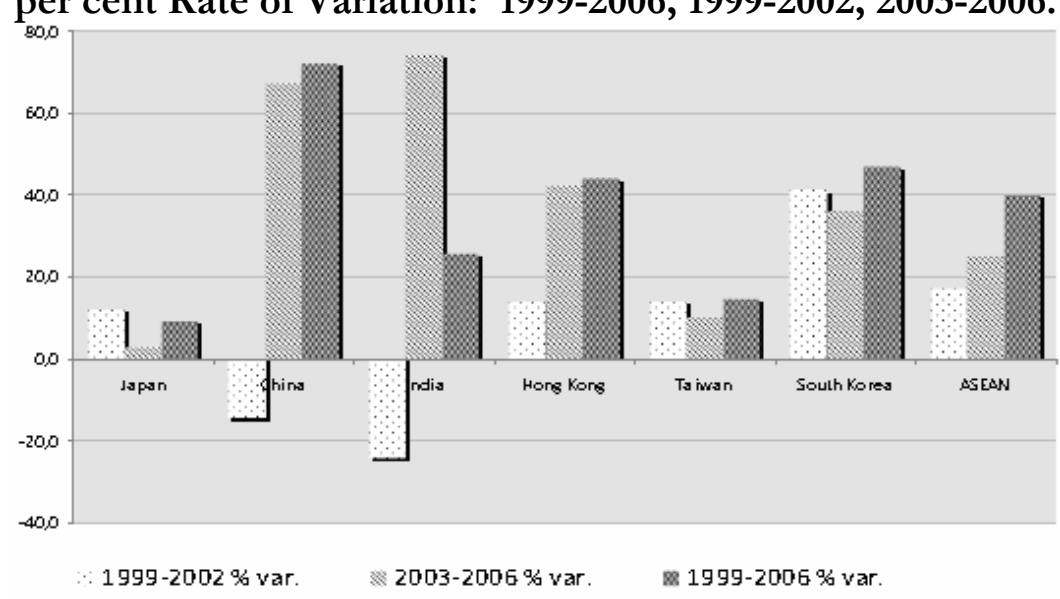

Source: Our elaboration, EUROSTAT 2006.

Table 11: European Imports of Agricultural Products from Selected Asian Countries (€Millions, 1999-2006).

\begin{tabular}{|l|r|r|r|r|r|r|r|r|}
\cline { 2 - 10 } \multicolumn{1}{c|}{} & \multicolumn{1}{c|}{$\mathbf{1 9 9 9}$} & \multicolumn{1}{c}{$\mathbf{2 0 0 0}$} & $\mathbf{2 0 0 1}$ & $\mathbf{2 0 0 2}$ & $\mathbf{2 0 0 3}$ & $\mathbf{2 0 0 4}$ & $\mathbf{2 0 0 5}$ & $\mathbf{2 0 0 6}$ \\
\hline Japan & 130 & 169 & 179 & 161 & 135 & 145 & 139 & 134 \\
\hline China & 1,757 & 2,156 & 2,192 & 2,083 & 2,081 & 2,180 & 2,547 & 2,856 \\
\hline India & 1,188 & 1,358 & 1,265 & 1,125 & 1,051 & 1,178 & 1,246 & 1,393 \\
\hline Hong Kong & 63 & 73 & 58 & 57 & 48 & 42 & 60 & 55 \\
\hline Taiwan & 53 & 58 & 67 & 61 & 58 & 50 & 49 & 53 \\
\hline South Korea & 42 & 55 & 42 & 49 & 47 & 48 & 39 & 40 \\
\hline ASEAN & 4,271 & 4,520 & 4,437 & 4,486 & 4,555 & 4,828 & 5,019 & 5,566 \\
\hline $\begin{array}{l}\text { Total imports } \\
\text { (agricultural } \\
\text { products) }\end{array}$ & 7,504 & 8,389 & 8,240 & 8,022 & 7,975 & 8,471 & 9,099 & 10,097 \\
\hline $\begin{array}{l}\text { Total imports } \\
\text { (all products) }\end{array}$ & 248,333 & 321,141 & 306,335 & 301,964 & 315,130 & 350,849 & 390,326 & 445,296 \\
\hline
\end{tabular}

Source: Our elaboration, EUROSTAT 2006.

EU imports of agricultural products from the selected Asian countries increased between 1999 and 2006 by 34 per cent, in comparison with 77 per cent for all products imports (See Table 11). 
Figure 2: Agriculture products: EU Imports from Selected Asian Countries: per cent Rate of Variation, 1999-2002, 2003-2006, 1999-2006

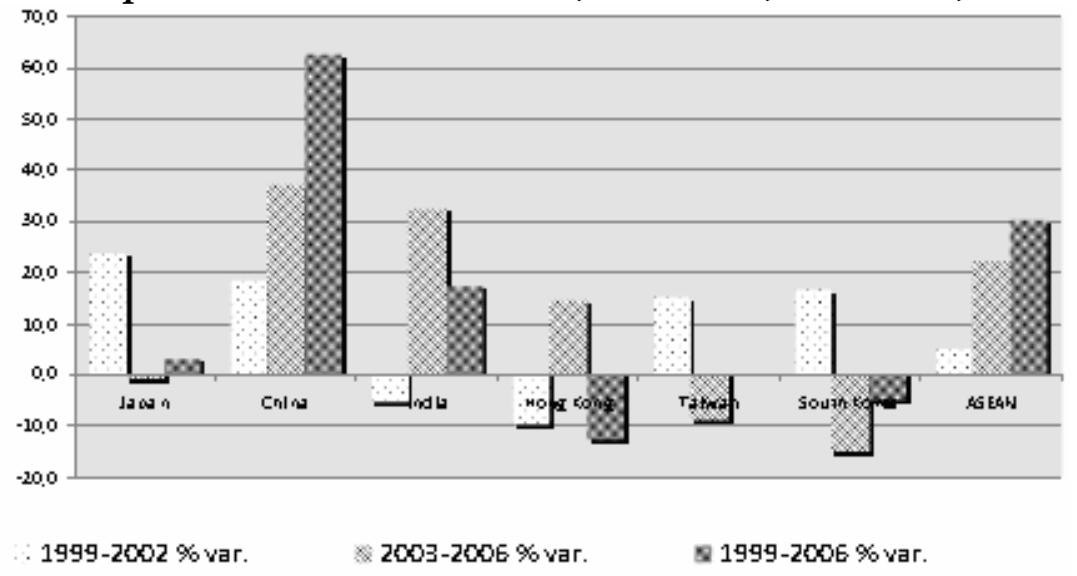

Source: Our elaboration, EUROSTAT 2006.

Regarding the EU's agricultural trade balance for the period 1999-2006, it has been generally positive, in contrast to the negative balance for all products. The agricultural trade balance was in deficit only in respect of ASEAN countries, China and India (See Table 12).

Table 12: Trade Balance in Agricultural Products: EU in Relation to Selected Asian Countries (€Millions, 1999-2006).

\begin{tabular}{|l|r|r|r|r|r|r|r|r|}
\cline { 2 - 9 } \multicolumn{1}{c|}{} & \multicolumn{1}{c|}{$\mathbf{1 9 9 9}$} & \multicolumn{1}{c|}{$\mathbf{2 0 0 0}$} & \multicolumn{1}{c|}{$\mathbf{2 0 0 1}$} & \multicolumn{1}{c|}{$\mathbf{2 0 0 2}$} & $\mathbf{2 0 0 3}$ & $\mathbf{2 0 0 4}$ & $\mathbf{2 0 0 5}$ & $\mathbf{2 0 0 6}$ \\
\hline Japan & 3,612 & 4,131 & 4,256 & 4,035 & 3,836 & 3,965 & 3,875 & 3,953 \\
\hline China & -960 & $-1,411$ & $-1,547$ & $-1,400$ & $-1,261$ & $-1,168$ & $-1,317$ & $-1,485$ \\
\hline India & -912 & $-1,204$ & $-1,083$ & -916 & -852 & -994 & $-1,049$ & $-1,046$ \\
\hline Hong Kong & 1,009 & 1,287 & 1,357 & 1,165 & 1,040 & 1,174 & 1,172 & 1,491 \\
\hline Taiwan & 606 & 719 & 694 & 690 & 628 & 659 & 689 & 702 \\
\hline South Korea & 769 & 921 & 928 & 1,097 & 830 & 925 & 1,042 & 1,153 \\
\hline ASEAN & $-2,470$ & $-2,142$ & $-2,194$ & $-2,375$ & $-2,536$ & $-2,599$ & $-2,641$ & $-5,042$ \\
\hline $\begin{array}{l}\text { Total } \\
\text { (agricultura } \\
\text { products) }\end{array}$ & 1,654 & 2,301 & 2,411 & 2,296 & 1,685 & 1,962 & 1,771 & 1,726 \\
\hline $\begin{array}{l}\text { Total (all } \\
\text { products) }\end{array}$ & $-110,984$ & $-141,947$ & $-122,542$ & $-119,159$ & $-133,599$ & $-149,549$ & $-175,339$ & $-206,963$ \\
\hline
\end{tabular}

Source: Our elaboration, EUROSTAT 2006.

The normalised trade balance index permits meaningful comparisons among countries by eliminating problems with the unit of measurement. The index range is between -1 and +1 (See Table 13). The normalised trade balance for agricultural products for the EU-25 with selected Asian countries is generally positive. The best market is Japan, followed by South Korea and Hong Kong, with values near to 1. However, negative figures, indicating a deficit, are observed for India, China and ASEAN countries. 
Table 13: Normalised trade balance in Agricultural Products: EU in Relation to Selected Asian Countries ${ }^{14}$ (1999-2006).

\begin{tabular}{|l|r|r|r|r|r|r|r|r|}
\cline { 2 - 9 } \multicolumn{1}{c|}{} & $\mathbf{1 9 9 9}$ & $\mathbf{2 0 0 0}$ & $\mathbf{2 0 0 1}$ & $\mathbf{2 0 0 2}$ & $\mathbf{2 0 0 3}$ & $\mathbf{2 0 0 4}$ & $\mathbf{2 0 0 5}$ & $\mathbf{2 0 0 6}$ \\
\hline Japan & 0.933 & 0.924 & 0.922 & 0.926 & 0.934 & 0.932 & 0.933 & 0.937 \\
\hline China & - & - & - & - & - & - & - & - \\
\hline India & 0.376 & 0.486 & 0.545 & 0.506 & 0.435 & 0.366 & 0.349 & 0.351 \\
\hline Hong Kong & 0.889 & 0.898 & 0.921 & 0.911 & 0.915 & 0.933 & 0.907 & 0.931 \\
\hline Taiwan & 0.851 & 0.861 & 0.838 & 0.850 & 0.844 & 0.868 & 0.875 & 0.869 \\
\hline South Korea & 0.902 & 0.893 & 0.917 & 0.918 & 0.898 & 0.906 & 0.930 & 0.935 \\
\hline ASEAN & 0.407 & 0.311 & 0.328 & 0.360 & 0.386 & 0.368 & 0.357 & 0.376 \\
\hline $\begin{array}{l}\text { Agriculture } \\
\text { products }\end{array}$ & 0.099 & 0.121 & 0.128 & 0.125 & 0.096 & 0.104 & 0.089 & 0.079 \\
\hline All products & 0.288 & 0.284 & 0.250 & 0.246 & 0.269 & 0.271 & 0.290 & 0.303 \\
\hline
\end{tabular}

Source: Our elaboration, EUROSTAT 2006

The export coverage index shows the extent to which a country's imports are compensated by exports. The index ranges from 0 (in case of no exports) to $+\infty$ (no imports). Deficits (values under 1) for trade in agricultural products are observed for China, India and ASEAN countries. Substantial surpluses are shown to be the case for Japan, Hong Kong and ASEAN countries (See Table 14).

14 The normalised trade balance is calculated as the ratio between the balance of trade (exports minus imports) and the trade volume (exports plus imports) 
Table 14: Export / Import Coverage and Growth Rates of Exports to the EU: agriculture products, selected Asian Countries ${ }^{15}$ (1999-2006).

\begin{tabular}{|c|c|c|c|c|c|c|c|c|}
\hline & \multicolumn{8}{|c|}{ Export/Import Coverage } \\
\hline & 1999 & 2000 & 2001 & 2002 & 2003 & 2004 & 2005 & 2006 \\
\hline Japan & 28.78 & 25.44 & 24.78 & 26.06 & 29.41 & 28.34 & 28.88 & 30.50 \\
\hline China & 0.45 & 0.35 & 0.29 & 0.33 & 0.39 & 0.46 & 0.48 & 0.48 \\
\hline India & 0.23 & 0.11 & 0.14 & 0.19 & 0.19 & 0.16 & 0.16 & 0.25 \\
\hline Hong Kong & 17.02 & 18.63 & 24.40 & 21.44 & 22.67 & 28.95 & 20.53 & 28.11 \\
\hline Taiwan & 12.43 & 13.40 & 11.36 & 12.31 & 11.83 & 14.18 & 15.06 & 14.25 \\
\hline South Korea & 19.31 & 17.75 & 23.10 & 23.39 & 18.66 & 20.27 & 27.72 & 29.83 \\
\hline ASEAN & 0.42 & 0.53 & 0.51 & 0.47 & 0.44 & 0.46 & 0.47 & 0.45 \\
\hline $\begin{array}{l}\text { Agriculture } \\
\text { products }\end{array}$ & 1.21 & 1.26 & 1.28 & 1.27 & 1.20 & 1.22 & 1.18 & 1.16 \\
\hline \multirow[t]{3}{*}{ All products } & 0.52 & 0.53 & 0.57 & 0.58 & 0.55 & 0.55 & 0.53 & 0.51 \\
\hline & \multicolumn{8}{|c|}{ Growth Rates of Exports } \\
\hline & 1999 & 2000 & 2001 & 2002 & 2003 & 2004 & 2005 & 2006 \\
\hline $\begin{array}{l}\text { Agriculture } \\
\text { products }\end{array}$ & 16.73 & -0.36 & -3.13 & -6.38 & 8.00 & 4.19 & 8.77 & 16.73 \\
\hline Al1 products & 30.47 & 2.57 & -0.54 & -0.70 & 10.89 & 6.80 & 10.86 & 30.47 \\
\hline
\end{tabular}

Source: Our elaboration, EUROSTAT 2006

Growth rates show how the value of European agricultural exports to the selected Asian countries has changed over the period 1999-2006 ${ }^{16}$. Most dynamic growth has been in respect of exports to China (+8.1 per cent) and to South Korea $(+5.7$ per cent). Analysing the sub- period 1999-2000, exports to South Korea show the best performance, while exports to India (-8.8 per cent) and to China ( -5.0 per cent) show the worst. Over the period 2003-2006 the overall growth rate improved thanks to increases to China ( +18.7 per cent) and to India $(+20.1$ per cent). It is worth mentioning that the annual rates generally showed negative values for the years 2001-2002 due to the terrorist attack on the USA that restrained international trade.

In respect of exports, we can compare the performance of those selected Asian countries in the WTO and those that are not in the WTO, and observe that there is a decreasing trend in terms of annual variations until 2003, and then a growing divergence (See Figs. 4 and 5). Those selected Asian countries outside the WTO vary in their performances with an overall strong decrease in 2003.

\footnotetext{
15 The export/import coverage is the ratio of total exports to total imports. The growth rate of exports is the annual compound percentage change in the value of exports between two periods.

16 As known it can take a value between -100 and $+\infty$.
} 
Figure 3 and 4: Selected Asian Countries: WTO vs non-WTO Countries: Exports (2000-2006) ${ }^{17}$
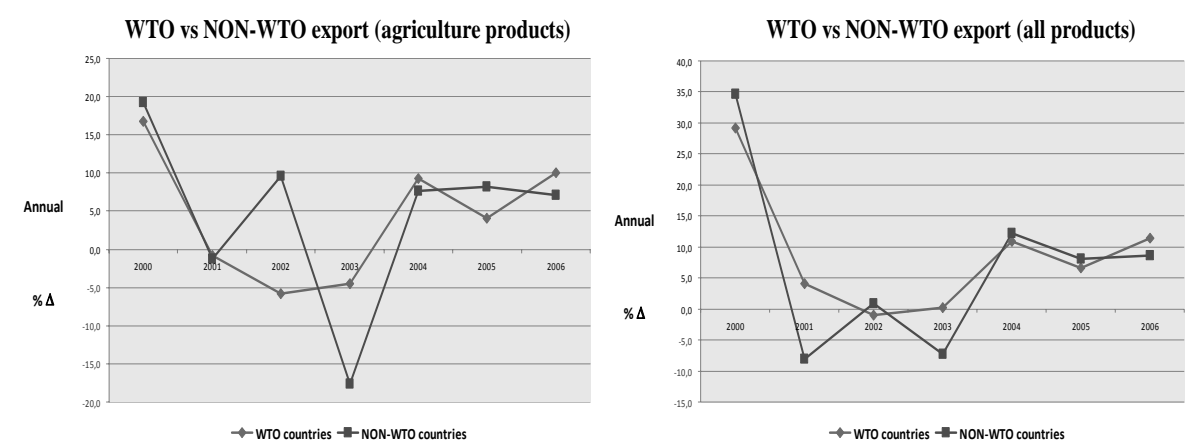

Source: Our elaboration, EUROSTAT 2006.

In respect of agricultural imports, non- WTO Asian countries have decreasing rates from 2000 to 2005, then they change trend (See Figs. 6 and 7). Instead, since 2003, the export of European agricultural products shows annual variations higher than those of all products.

An analysis of agricultural export product categories shows that the "beverages, spirits and vinegar" category is the most important for agricultural exports to the EU from the selected Asian countries. It accounts for 26 per cent of agricultural exports from India, 25 per cent from ASEAN countries, 19 per cent from China, 25 per cent from South Korea, and 38.5 per cent from Taiwan. "Meat and edible meat offal" is important for Japan (19 per cent of agricultural exports), Hong Kong (10 per cent), and South Korea (27 per cent). Cereals are significant for India (31 per cent), "products of animal origin" for China (5 per cent), and "dairy produce" for ASEAN countries (16 per cent).

Figure 5 and 6: Selected Asian Countries: WTO vs non WTO Countries: Imports (2000-2006)
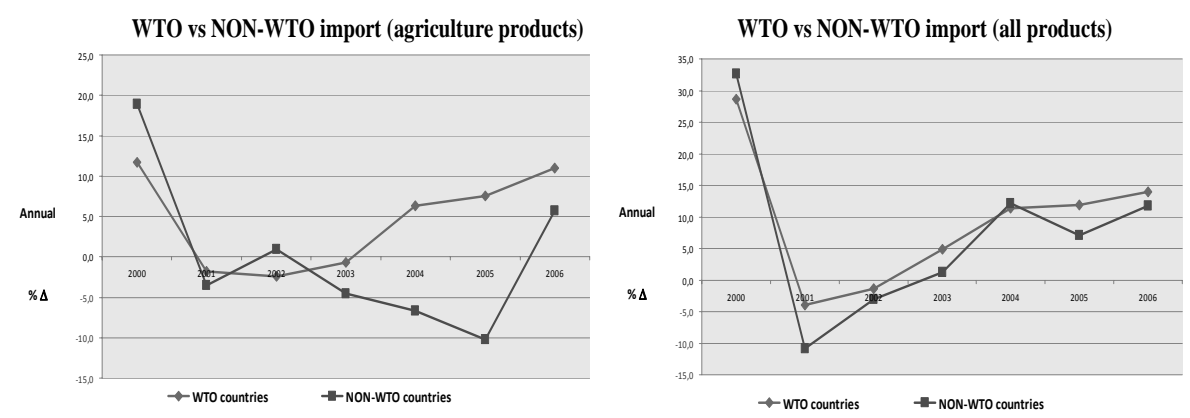

Source: Our elaboration, EUROSTAT 2006

\footnotetext{
17 WTO countries are Japan, China, India, ASEAN Hong Kong, Singapore. Non WTO countries are Taiwan and Korea. Every ASEAN country belongs to WTO except Lao People's Democratic Republic. As Lao's is a small country proportionately to ASEAN total population and GDP, we considered that whole ASEAN belongs to WTO.
} 
For the European Union "beverages, spirits and vinegar" are the most important category of agricultural exports to the selected Asian countries, followed by "meat, cereals and by- products". Five product categories each account for more than 10 per cent of EU agricultural exports to individual selected Asian countries. In respect of EU agricultural imports, for different product categories, we can see that they are less concentrated than for exports. For imports, about 14 product categories have a share higher than 10 per cent of total EU agricultural imports from individual selected Asian countries or from ASEAN. "Animal or vegetable fats and oils" make up 36 per cent of EU agricultural imports from ASEAN countries", "coffee, tea, mate and spices" are important for imports from ASEAN countries (16 per cent) and from India (22 per cent), "preparations of vegetables, fruits, nuts and plants" from China (17 per cent), "edible vegetables, roots and tubers" and "products of animal origin" from China (respectively 14 per cent and 13 per cent), "edible fruits and nuts from India" (17 per cent), "miscellaneous edible preparations" from Japan (19 per cent) and Hong Kong (31 per cent), "oil seeds and oleaginous fruits" from Japan (15 per cent), "live animals" from Hong Kong (27 per cent), "live trees and other plants" from Taiwan (23 per cent), "preparations of cereals, flours, starch etc" and "tobacco and tobacco products" from South Korea (24 per cent and 16 per cent respectively).

\section{Concluding remarks}

For many years, the European agricultural policy has followed the mercantilists' advice: it has provided export subsidies while establishing import tariff barriers.

The recent Fischler reform, together with progressive reforms adopted by some Asian countries, have brought about a general free market price re-orientation, and generally a more open market, characterised by a reduction of trade distortions, albeit that at the European level, welfarism and protectionist structures remain.

The gap in terms of productivity among the EU-25 and the selected Asian countries has been confirmed in this paper. Globally, the production of cereals and meat has increased, but average productivity measured in terms of output value relative to agricultural population, territory or available arable area is highest in the EU.

In respect of land and labour production factors, the indices have underlined the higher dynamism of the ASEAN cluster for cereals, and of China for meat. In fact, in the latter regard, the EU has been surpassed by China since the Eighties. In terms of the arable land factor relative increase, the performances of the 
ASEAN cluster over the decade 1990-2000) and then by India over the decade 1980-1990 stand out.

The examination of data referring to import- export flows between the EU-25 and the selected Asian countries over the period 1999-2006 allows us to offer some thoughts on the first effects of evolving liberalisation.

At the world level, the EU is a very important market. As an importer and exporter it is only second to the United States. Its role in international trade is crucial. With some areas or countries its balance of trade is positive, particularly so with some countries, such as Japan. In contrast, the highest trade deficits are with: NAFTA countries ${ }^{18}$, Australia, New Zealand and China.

The EU has over the period considered experienced a growing nominal trade deficit in respect of trade in all products with the analysed Asian countries. The trade balance in respect of agricultural products, however, has remained positive. Much of the growth in demand has originated in China and India, although Japan remains the most important market, for the European exports. Over the period 1999 - 2006 European agricultural imports grew at a rate of 34.2 per cent, almost 4 percentage points more than exports.

A complex situation appears when analyzing data for different products. The biggest trade deficits are in animal or vegetable fats and oils, coffee, tea, mate and spices. These products are not in direct competition with European production. However, the EU has a comparative advantage in beverages, cereals and food production (higher value and processed foods). But these advantages are steadily decreasing. In Europe, labour and land average productivity levels are high but they will decline because of the decreasing marginal productivity law.

If we distinguish between WTO and non-WTO countries we see a dissimilar trend for agricultural products and all products. In respect of agricultural products, imports to the EU from WTO countries exhibit a growing trend, and the same is the case for all products. However, imports from non-WTO countries are tending to decrease. Exports in agricultural products from the EU to WTO countries had a negative trend until 2003, then they recovered with annual variations higher than was the case for all products. Generally, EU export and import trends for agricultural products demonstrate strong variations if we consider all agricultural products as a whole.

For WTO countries, however, import-export flows are more constant.

It is worth pointing out that trade exchanges can be influenced by non-economic factors and events. For example, slowdowns observed in international trade in 2001 and 2002 are an effect of the terrorist attack in the USA on 11 th September 2001.

${ }_{18}$ North American Free Trade Area. 
However, levels of protection are still high and the design of impartial policies is compromised by the power of vested interests - agricultural lobbies have ensured the inclusion of specific rules in the major international agreements that permit more protectionist measures in agriculture than in other sectors and by the powerlessness of governments to find balanced solutions that could help achieve a range of significant goals such as food safety, the redistribution and transfer of incomes and the production of high added value products (Ataman, Beghin, 2004).

\section{References}

Ataman A.M., Beghin J.C., Global agricultural trade and developing countries, World Bank, 2004.

Daugbjerg C., Swinbank A., The politics of CAP Reform: trade negotiations, institutional settings and blame avoidance, JCMS, 2007, nro 45.

European Commission, Communication from the Commission to the Council and European Parliament Mid-term review of the Common Agricultural Policy, Brussels, 2002.

European Commission, Directorate-General of Agriculture, The CAP Reform - a Policy for the future, Brussels, 1999.

European Commission, Directorate-General of Agriculture, Agenda 2000. CAP Reform Decision. Impact Analysis, Brussels, 2000 .

EUROSTAT, Agricultural trade statistics - EU 25: Trade in value by chapter as defined in the Uruguay Round Agreement, 2006, http://ec.europa.eu/agriculture/agrista/tradestats/2006

FAO, The state of food and agriculture, Rome, FAO, 2007, Agriculture Series No. 38.

Government of India, Agriculture sector, National Portal of India, 2008, www.india.gov.in

Rose A. K., Do WTO members have more liberal trade policy?, Journal of International Economics, 2004, Issue 2, Volume 63.

World Bank, Agricultural Market Access: The key to Doha success, The World Bank Group, 2005, Trade Note 23. 